\title{
Knowledge: A Verb or a Noun in Education for Sustainable Development
}

\author{
Fouzia Khanam, Zebun Nisa Khan \\ Department of Education, Aligarh Muslim University, Aligarh, India \\ Email address: \\ fouziakhan19@gmail.com (F. Khanam), zebunnisakhan@yahoo.com (Z. N. Khan)
}

To cite this article:

Fouzia Khanam, Zebun Nisa Khan. Knowledge: A Verb or a Noun in Education for Sustainable Development. International Journal of Elementary Education. Vol. 5, No. 6, 2016, pp. 58-62. doi: 10.11648/j.ijeedu.20160506.11

Received: September 21, 2016; Accepted: October 6, 2016; Published: November 18, 2016

\begin{abstract}
Knowledge is the fact of knowing about something, general understanding or familiarity with the subject. The goal of quality education for Sustainable development is achievable, if, knowledge of Sustainable development is understood in a right direction. Knowledge according to revised Bloom's Taxonomy has two dimensions; knowledge as theory in content, and knowledge as action in verbs, making a taxonomical grid. The present efforts in education is more towards ESD knowledge as content than knowledge as action, that makes scope of ESD very limited. In the present study a comparative analysis of the students of Madrasa and Non Madrasa background (the two very different medium of instruction) was given a questionnaire to test their knowledge content about Sustainable development. The conclusion is drawn according to the result done on the premise developed earlier.
\end{abstract}

Keywords: Knowledge, Education for Sustainable Development (ESD), Madrasa, Curricula, Taxonomy, Environmental

\section{Introduction}

Awareness, understanding, or information that has been obtained by experience or study, and that is either in a person's mind or possessed by generally (Cambridge Dictionary) [9]. This definition of knowledge here explains; the information attained by experience, that is either in the mind (inside) or possessed, i.e. by external environment. Knowledge exists in various forms, one that exists explicitly and other that is implicit in its nature. Knowledge that exists explicitly is the content of knowledge acquired through cultural heritage in years, and other is the implicit knowledge, exists in the form of cognitive strategies, also known as cognitive domain in Bloom's Taxonomy (Krathwohl [8]). So the knowledge acquired by cultural heritage and scientific advancement can be considered in the form of noun, and knowledge as a verb is consecutively the cognitive strategies needed to attain this explicit knowledge.

Therefore, knowledge as a noun is the goal, and knowledge as verb is means. Furthermore, Hindu mythology where bow, arrow and its string plays a very significant role explains it as follows:

- It is nearly in every deities hand and it explains the balance; so the target can be explained as the knowledge possessed (Noun) known as truth.

- The arrow is wisdom of knowledge (Verb).

There is a string that has to be balanced, if it is too tight, or too loose it will not hit the target, the arrow will hit the target only when the string is balanced and education is the way of balancing this string. The researcher view of Sustainability as a verb, is supported by Jones [7], cited by Giri [5], explains that Sustainability is not only Noun but also a Verb, and the movement of establishing Sustainable development is losing basis of being proactive whereas Sustainable development is in fact a Verb or a manifold of Verb of meditation, transforming of self and society. Further, Giri [5], in his own work supports the concept of Sustainability as a Verb, and it is not only related to economic, but embraces many fields and aspiration of life and society. Though this work has not been done in the field of education, but the curriculum pattern followed in India, has a more theoretical approach, than considering sustainability as not something to be crammed about but a movement of change of individual's choice. So, this developed an insight to write a research paper on the respondent of different curriculum. 


\section{Significance of the Study}

The soul aim of any education is to attain knowledge, knowledge which benefits mankind, knowledge which is sustainable; which takes care of the present generation and preserve the need of the future generation. Attaining Sustainable development is attaining balance, this balance is the need of hour, because of the chaos present due to knowledge explosion, and everything which is studied is leading us to our common future. The future which we think is better than today, and which is moving us away from our better common future. Is it our consolidated knowledge or the strategies we use to attain this knowledge. The answer may be hidden or apparent, technical or easy, but answer has to be there, this means something is missing. Efforts were made to improve our curriculum, but is it reaching the end in a right way or not. The present study is just to focus on this very miniature but central issue of education for Sustainable development (Hargreaves \& Fink [6]).

\section{Objectives}

The objectives were framed as follows:

- To study if Knowledge of Sustainable development depends on the curricula.

- To study if Knowledge of Sustainable development is sufficient.

- To study ways to improve the curriculum that connects the knowledge as Noun and as a Verb.

- To compare the performance of Madrasa and Nonmadrasa student in the direct (Noun) and indirect (Verb) Knowledge of Sustainable development.

- To compare the performance of Madrasa students and Non-madrasa students on direct (Noun) and indirect (Verb) Knowledge of Sustainable development in the three dimensions of sustainability.

\section{Methodology}

The present study is of mixed approach, the sample collected was purposive; 666 students, 333 each of Madrasa pass outs and Non-madrasa pass outs were taken for the study. Each individual was given a set of 30 questions, containing environmental, social and economic questions (10 each). Each dimension contains 7 indirect and 3 direct questions related to Sustainable development. To make the students comparable, each group was taken from student who were simultaneously preparing for the same level entrance examination and they were explained the concept of Sustainable development (according to the definition of Brundtland Commission) and the test was conducted. The simple percentage, significant mean difference and t-test are applied using SPSS to analyse the data and interpret the data qualitatively to reach the valid conclusions.

\section{Knowledge, as a Noun and as a Verb, ESD}

Benjamin S. Bloom (1956) tried to develop taxonomy of educational objectives, which classified the statement intended for students to learn. Knowledge was given the first level of this taxonomical structure(Mangal \& Mangal [10]), later on this structure was redefined and converted into two dimensional structure, knowledge as a noun and knowledge as a verb. Knowledge as a noun is classified as factual, conceptual, procedural and metacognitive. Knowledge as a verb is defined by the sets of action verbs arrange in hierarchical way, for example; remember, understand, apply, analyse, evaluate and create. These verbs are the cognitive strategies to encompass the knowledge, and here comes our field of interest. The education for Sustainable development so far given is through knowledge of lower domain. The attention on incompetence of the transaction of this knowledge to action lies behind the fact that higher dimensions of the action, verb has not been still achieved (Fouzia et. al. [4]). Keeping this in mind we are trying new ways to reach Sustainable development by exploring the different ways of curriculum instructions. In the present study, we took two groups of students using different ways of curriculum instructions that are basically contrary to each other. One is giving divine and religious knowledge of centuries, and the other is giving consolidated knowledge of human being. The Madrasa students defines the first group and group of students of different boards (CBSE, UP Board, AMU Board, and Bihar Board) constituted the second group known as Non-madrasa students. These two groups were examined on the knowledge of Sustainable development which signifies directly and indirectly. Direct knowledge of Sustainable development as 'Noun' is people who may know /remember the concept of sustainability but may not understand and apply that concept in real life while for 'Verb', they know it, heard about it, read it but actually they don't practise it. There may be people who are not well versed, and had not known the world level propaganda of the concept of Sustainability but are actually practising it. It is actually there in the value and belief system of their environment, through which we can add at least a comma to the understanding of the concept and practise it.

\section{Analysis and Interpretation of Data}

- To compare the performance of Madrasa students and Non-madrasa students in the knowledge of Sustainable development. The above objective was fulfilled:

(i) Taking Mean of the score obtained by the Madrasa students and Non-madrasa students by the items checking direct knowledge and indirect knowledge of Sustainable development.

After comparing the means of Madrasa students and Nonmadrasa students both on direct and Indirect questions on Sustainability it was found that students of Madrasa students and non- madrasa students has higher mean Indirect 
questions on Sustainability as compare to students of Madrasa students and non- madrasa students in direct questions on Sustainability. The mean of Madrasa students
$\left(\mathrm{M}_{1}=16.5135\right)$ was found to be higher as compare to the mean of non- madrasa students $\left(\mathrm{M}_{2}=16.0871\right)$ in Indirect questions on Sustainability.

Table 1. Comparing Mean of Madrasa and Non-madrasa Students.

\begin{tabular}{|c|c|c|c|c|c|c|}
\hline Type of question & Type of school & Number & Mean & $\begin{array}{l}\text { Standard } \\
\text { deviation }\end{array}$ & t-value & Level of significance \\
\hline \multirow{2}{*}{ Direct questions } & Madrasa & 333 & 6.9009 & 1.62597 & \multirow{2}{*}{-1.67} & \multirow{4}{*}{$\begin{array}{l}\text { Not Significant at. } 05 \text { level } \\
\text { of confidence } \\
\text { Significant at. } 05 \text { level of } \\
\text { confidence }\end{array}$} \\
\hline & Non-_Madrasa & 333 & 6.9219 & 1.61504 & & \\
\hline \multirow{2}{*}{ Indirect questions } & Madrasa & 333 & 16.5135 & 2.22336 & \multirow[t]{2}{*}{2.614} & \\
\hline & Non-_Madrasa & 333 & 16.0871 & 1.97916 & & \\
\hline
\end{tabular}

Comparing the means, it can be drawn that Madrasa students scored greater than non- madrasa students in on Indirect questions on Sustainability.

(ii) Calculating the percentage of the responses made by both the groups on questions of indirect and direct knowledge of Sustainable development, we noticed that percentage of Madrasa students having right responses were distinctively greater than Nonmadrasa students in both direct and indirect questions of 'Knowledge of Sustainable development'.

Table 2. Comparing Percentage of Both students on Direct and Indirect Knowledge of Sustainable Development.

\begin{tabular}{lllll}
\hline \multirow{2}{*}{ Item } & \multicolumn{2}{l}{ Madrasa Students } & \multicolumn{2}{l}{ Non-madrasa Students } \\
\cline { 2 - 5 } & Right & Wrong & Right & Wrong \\
\hline Indirect & 78.2 & 21.8 & 65.31 & 34.68 \\
Direct & 81.48 & 18.51 & 65.99 & 34.00 \\
\hline
\end{tabular}

- To compare the performance of Madrasa students and Non-madrasa students (percentage) on direct and indirect knowledge of Sustainable development in the three dimensions of Sustainability.

The above objective was fulfilled by calculating the percentage of student giving right and wrong among the total response for each dimension, so drawing out the table and pie chart helped us reach to some conclusion.

(i) Knowledge of Sustainable development (Environmental)

Table 3. Comparing Knowledge of Environmental Sustainable Development.

\begin{tabular}{lllll}
\hline \multirow{2}{*}{ Item } & \multicolumn{2}{c}{ Madrasa Students } & \multicolumn{2}{c}{ Non-madrasa Students } \\
\cline { 2 - 5 } & Right & Wrong & Right & Wrong \\
\hline Indirect & 76.08 & 23.91 & 74.78 & 25.21 \\
Direct & 84.84 & 15.15 & 77.77 & 22.22 \\
\hline
\end{tabular}

Using above data Pie Charts were plotted between direct as well as indirect environmental Sustainability of Madrasa and Non-madrasa students.

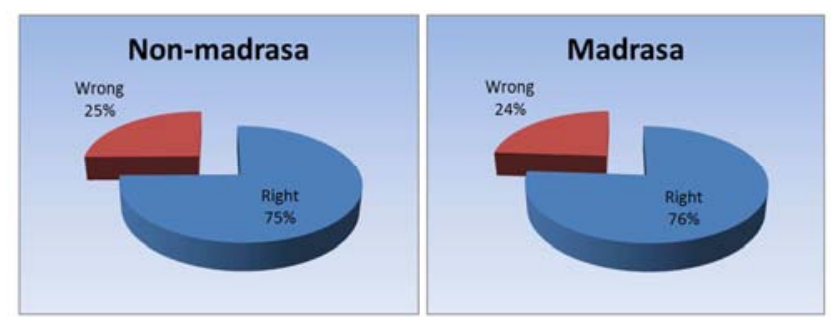

Figure 1. Comparison between Indirect Environmental Sustainability of Madrasa and Non-madrasa students.

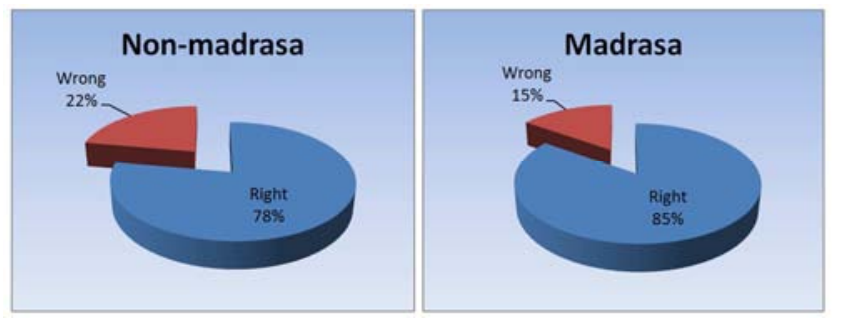

Figure 2. Comparison between Direct Environmental Sustainability of Madrasa and Non-madrasa students.

Studying the pie chart and tables we can say that the Madrasa students have better knowledge of environmental Sustainable development than the Non-madrasa students in both cases.

(ii) Knowledge of Sustainable development (Social)

Table 4. Comparing Knowledge of Social Sustainable Development.

\begin{tabular}{lllll}
\hline \multirow{2}{*}{ Item } & \multicolumn{2}{l}{ Madrasa Students } & \multicolumn{2}{l}{ Non-madrasa Students } \\
\cline { 2 - 5 } & Right & Wrong & Right & Wrong \\
\hline Indirect & 87.12 & 14.78 & 64.01 & 35.98 \\
Direct & 78.78 & 21.21 & 54.54 & 45.54 \\
\hline
\end{tabular}

Using above data Pie Charts were plotted between direct as well as indirect social Sustainability of Madrasa and Nonmadrasa students.

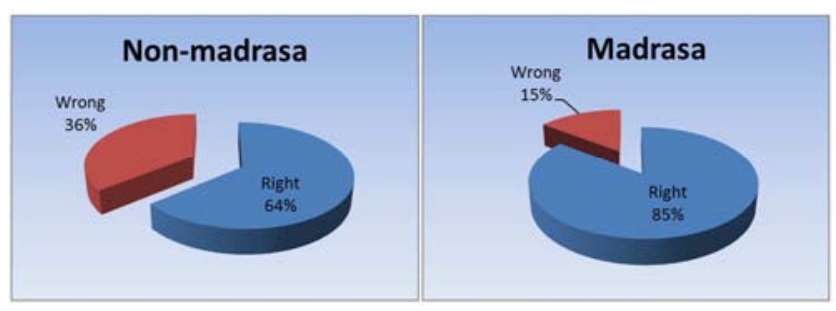

Figure 3. Comparison between Indirect Social Sustainability of Madrasa and Non-madrasa students.
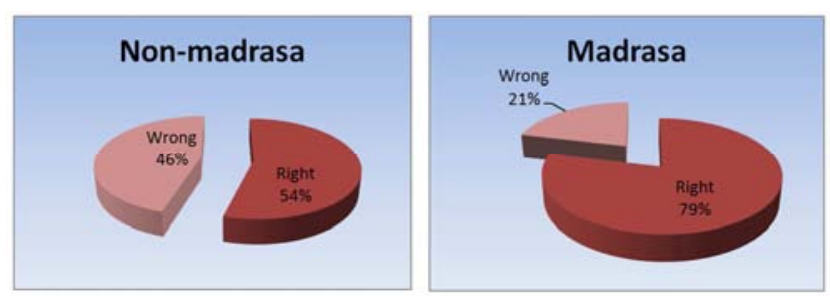

Figure 4. Comparison between Direct Social Sustainability of Madrasa and Non-madrasa students.

Studying the pie chart and tables we can say that the 
Madrasa students have better knowledge of Social Sustainable development than Non-madrasa students in both cases.

(iii) Knowledge of Sustainable development (Economic)

Table 5. Comparing Knowledge of Economic Sustainable Development.

\begin{tabular}{lllll}
\hline \multirow{2}{*}{ Item } & \multicolumn{2}{l}{ Madrasa Students } & \multicolumn{2}{l}{ Non-madrasa Students } \\
\cline { 2 - 5 } & Right & Wrong & Right & Wrong \\
\hline Indirect & 68.68 & 31.31 & 56.06 & 43.93 \\
Direct & 80.80 & 19.19 & 65.65 & 34.34 \\
\hline
\end{tabular}

Using above data Pie Charts were plotted between direct as well as indirect economic Sustainability of Madrasa and non-madrasa students.

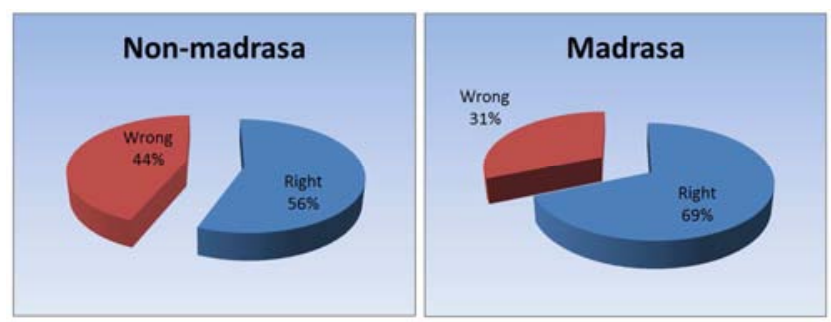

Figure 5. Comparison between Indirect Economic Sustainability Question of Madrasa and Non-madrasa students.

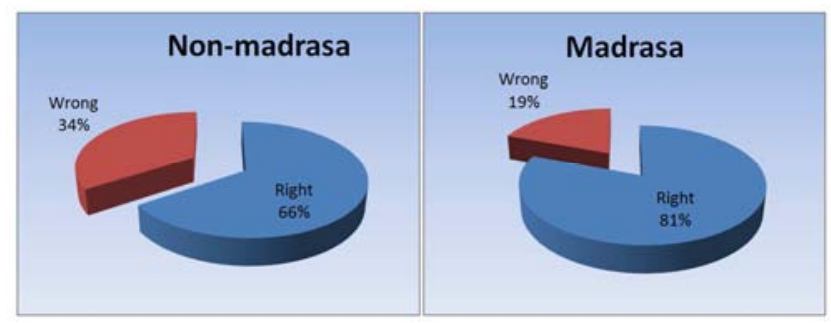

Figure 6. Comparison between Direct Economic Sustainability Question of Madrasa and Non-madrasa students.

Studying the pie chart and tables we can say that the Madrasa students have better knowledge of economic Sustainable development than Non-madrasa students both directly or indirectly.

\section{Discussion and Conclusion}

Achieving the objective (1) and (2) we conclude that Knowledge of Sustainable development seems not to be dependent on the curricula, as in all the analysis the mean and percentage shows that Madrasa student performed better than Non-madrasa students, even the direct knowledge is nearly insignificant with the name of Sustainable development. This is in consonance with the views of Basheer K, M. [1]. They also performed better in direct questions on sustainability, as the researcher explained the concept to both the group before taking the test, so the indirect and direct knowledge coherently existed in Madrasa students, whereas Non-madrasa students performed lower than their counterparts in all the dimensions of sustainability in both direct and indirect questions of sustainability even though the concept of sustainability and environmental education is embedded in nearly all the boards of India. Although this conclusion cannot be generalise, as the sample size is small and is also selected purposely as both the students receive different standards of education, but these result do come out with some question on the definition of education for sustainable development.

So the traditional ways of imparting the knowledge of Sustainable development is on question, are the goals of 'Education for Sustainable development' only to achieve environmental sustainability or promoting sustainable value and practises. Sustainable development shall not be achieved unless and until we pay attention on the process of cognitive understanding and application of knowledge, and also acknowledge the knowledge coming from different source that can help in building the better common future. Khan [7] expressed the need of women education as per their needs to have respect in society by means of Madrasa or Non-madrasa system. Thus, the need of the hour is to open a space for a new question, a new way of defining the goals of education for sustainable development.

The study has a very micro implication to evolve questions on the way world is seeing sustainability, it cannot contradict or channelize the world discussions on sustainability and education for Sustainable development. Though Madrasa and various similar institutions may not give technical knowledge of sustainability, i.e., Noun but may give the essence of sustainability in their very core of knowledge acquisition and practise Verb. This means any institution cannot function alone and fantasize of its perfection and completeness in any way not even Madrasa, it has to work by interacting with each other. Fahimuddin [3] also advocated similarly views in his book regarding the education of Madrasa students in Islamic preview. So if the knowledge of Sustainable development is given such that it has no stress on practice, i.e., Verb or on Noun simultaneously, the goals of Education for Sustainable development will never be achieved, and Sustainable development will become a subject, a theory or a concept, that will be crammed and remembered in student community for years without practise. And, thus knowledge as a Verb has to be linked to Noun through ESD to achieve the goals of Sustainable development and new ways of defining sustainability should be kept open as this paper had made an attempt to do so.

\section{References}

[1] Basheer K, M. (2013): Future of Indian Madrasah Education in the Globalised World. Scholarly Research Journal for Interdisciplinary Studies, 2(7), 95-102. ISSN 2278-8808.

[2] Bloom, B., Englehart, et. al. (1956): Taxonomy of Educational Objectives: The Classification of Educational Goals. Handbook I: Cognitive Domain. New York, Toronto: Longmans, Green.

[3] Fahimuddin (2004): Modernisation of Muslim Education in India.Adhyayan Publisher \& Distributers, Delhi, India. 
[4] Fouzia, K., Nikhat, A. \& Khan, Z. N. (2016): Transaction of Science Curriculum towards Sustainable Development: Sustainable Wheel of Science Curriculum. International Conference on 'Education as a Driver for Sustainable Development Goals', organized by the Centre for Environment Education (CEE), Ahmedabad, India, in Collaboration with UNESCO, UNEP and Government of India. (unpublished).

[5] Giri, A. K. (2013). Rethinking Sustainable Development: Self Development, Social transformations and Planetary Realization.

[6] Hargreaves, A., \& Fink, D. (2006): Sustainable Leadership. Jossey-Bass.S, U.S.A. ISSN: 978-0-7879-6838-0.

[7] Jones, P. Selby, D. and Sterling, S. (2010). Sustainability Education: Perspectives and Practice across Higher Education. Earthscan: London \& Washington, DC.
[8] Khan, Z. N. (2016): Women Empowerment: An Islamic Preview. Indian Journal of Psychometry and Education, 47(2), 161 - 166. ISSN: $0378-1003$.

[9] Krathwohl, D. R. (2002): A Revision of Bloom's Taxonomy: An Overview. Theory into Practise, 41(4), 212-218. ISSN: 00405841.

[10] Knowledge(n.d).Indictionary.cambridge.org. Retrivedfrom $\mathrm{http}$ //dictionary.cambridge.org/dictionary/english/knowledge accessed on March 12, 2016.

[11] Mangal, S. K., \& Mangal, S. (2009): Teaching of Physical Science. Meerut: Bhagwati Printers.

[12] S. Nautiyal et. al. (2013): Knowledge Systems of Societies for Adaptation and Mitigation of Impacts of Climate Change, Environmental Monitoring and Assessment, 153 (1-4): 253271. DOI: $10.1007 / 978-3-642-36143-2$ 1. 